Annals of Warsaw University of Life Sciences - SGGW

Land Reclamation No 42 (1), 2010: 69-77

(Ann. Warsaw Univ. of Life Sci. - SGGW, Land Reclam. 42 (1), 2010)

\title{
Variability of bedload transport rate during flood flows in the Zagożdżonka River
}

\author{
ZBIGNIEW POPEK \\ Department of Hydraulic Engineering and Environmental Restoration, Warsaw University of Life \\ Sciences - SGGW
}

\begin{abstract}
Variability of bedload transport rate during flood flows in the Zagożdzonka River. The paper presents the measurement results of bedload sediment transport during the flood flows observed in the Zagożdżonka River. The point for measuring the bedload transport, equipped with sediment catcher, devices for continuous measurements, and automated data recording, was localized above the Czarna gauge station in catchment studied by the Department of Hydraulic Engineering and Environmental Restoration, Warsaw University of Life Sciences - SGGW. The results of bedload transport measurements during one of the flood flow waves were compared to those calculated by using the Bagnold's formula. To determine the critical bed-shear stress, the Author's formula resulting from laboratory experiments, was used. Calculated variability of bedload transport rate during analyzed flood flow wave apparently differed from that directly measured. Nevertheless, mass of bedload achieved from calculations was lower by $6 \%$ than that from measurements, which can be considered as good result consistence.
\end{abstract}

Key words: bedload, transport rate, flood flow wave, small lowland river.

\section{INTRODUCTION}

Bedload transport is characterized by great variability of temporary intensities. It is mainly associated with the transport mechanism of bedload that - under conditions of lower flow regime and for sandy material - is transported in a form of bottom ripples and dunes with changing size and shape. It makes that even under steady flow conditions, the bedload transport rate varies in time, which was recorded both in laboratory and in in situ studies (Skibiński 1976; DVWK 1992; Hoey 1992; Shen 1998; Popek 2006).

During the flood event, when hydraulic flow parameters quickly vary, bedload transport is characterized by apparently higher variability than under steady flow conditions. The histeresis phenomenon occurs along with considerable increase of bedload transport rate, which can be observed from a dependence between the flow rate vs. bedload transport rate. It can be recorded only when parameters of water flow and bedload transport are continuously measured (Reid et al. 1985; Kuhnle 1991). The device for continuous recording of water stage and mass of bedload trapped in the catcher placed on the river bottom, was applied in own study performed in natural bed of small lowland river with sandy bottom (Popek 2006).

Up-to-date results obtained from own studies and those achieved by other authors, have not yet allowed for deter- 
mining the strict dependences that would describe the bedload transport during unsteady flow during flood flow waves. An intensive transport of bedload in such conditions and associated erosion processes significantly affect on the morphology and stability of river bed. Therefore, possibility to determine the actual values of bedload rate during those events is of a great practical importance, because knowledge on the influence of proposed solutions on a river bed stability and its morphology, is a significant designing element in river engineering. In turn, determining the course of sedimentation processes is important in the case of water reservoir designing.

Thus, the study presents the attempt to apply the empirical Bagnold's formula for determining the bedload transport rate during the flood flow wave, i.e. under unsteady flow conditions.

\section{MATERIAL AND METHODS}

The point for bedload transport measurements was localized in natural bed of the Zagożdżonka River above the Czarna gauge station within the catchment studied by the Department of Hydraulic
Engineering and Environmental Restoration, Warsaw University of Life Sciences. In the Czarna profile, the catchment of the Zagożdżonka river is of $23.4 \mathrm{~km}^{2}$ surface area, with mean annual discharge of about $0.08 \mathrm{~m}^{3} \cdot \mathrm{s}^{-1}$. The riverbed within studied section is characterized by following parameters: riverbed width at water surface $-3 \div 4 \mathrm{~m}$, bottom width $-2 \div 3 \mathrm{~m}$, maximum depth $-0.6 \div 0.7 \mathrm{~m}$, longitudinal bottom slop - about $1 \%$, the bed material is composed of medium sand of $d_{50}=0.41 \mathrm{~mm}$ particle diameter. The measurement station was equipped with devices for continuous measuring, automatic recording of water stages, and mass of bedload trapped in a catcher, the scheme of which is presented on Figure 1. In general, the bedload catcher consists of two containers of $0.75 \times 0.75 \times 0.63 \mathrm{~m}$ dimensions each and total volume about $0.7 \mathrm{~m}^{3}$, underneath of which the sensors for measuring the weight of bedload that was accumulated in containers, are mounted (Popek 2006).

The Bagnold's formula was applied to calculate the bedload transport rate during flood flow waves (1986); the formula was derived on a base of in situ surveys and in laboratory under steady

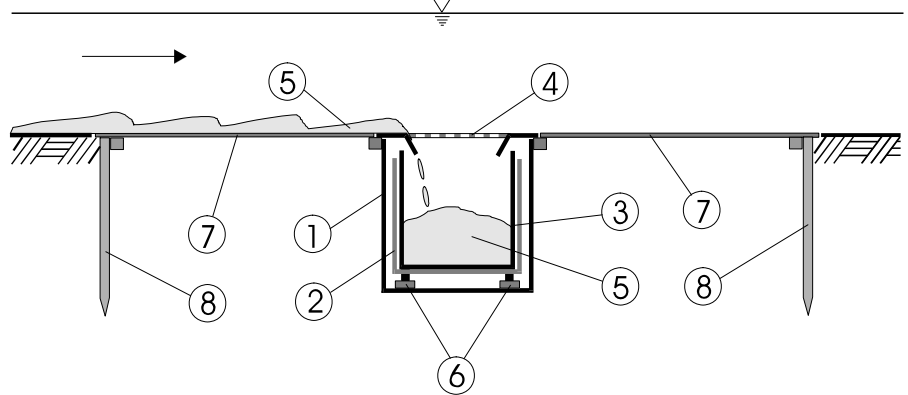

FIGURE 1. Scheme of bedload catcher: 1 - cover container, 2 - bearing frame, 3 - container for sediment, 4 - container's cover with steel net, 5 - bed form, 6 - weight sensors, 7 - wooden floor, 8 - wooden palisade 
water flow conditions. Following reasons determined the choice of the Bagnold's formula:

- theoretically proven general form of the dependence and dimensionless form of the detailed dependence,

- wide range of analyzed study results, on a base of which the values of constant parameters in the dependence are determined,

- possibility to use own study results to determine the critical bed-shear stress values for sediments collected from the Zagożdżonka riverbed,

- great conformity of values calculated according the formula with those from measurements under steady flow conditions made by the Author (Popek 2006) and other researchers in Poland (Bartnik and Michalik 2000; Michalik 2000).

Bagnold connected the bedload transport rate with unit water stream force $\omega$, defined as a product of shear stress at the bottom $\tau_{b}$ and mean water flow velocity $V$ :

$$
\omega=\tau_{b} \cdot V
$$

although shear stress at the bottom $\tau_{b}$ can be expressed in mass units $\left[\mathrm{kg} \cdot \mathrm{m}^{-2}\right]$ :

$$
\tau_{b}=\rho_{w} \cdot h \cdot S
$$

hence unit water stream force $\omega$ is expressed in $\left[\mathrm{kg} \cdot \mathrm{s}^{-1} \cdot \mathrm{m}^{-1}\right]$. Following designations were accepted in equation (2): $\rho_{w}$ - water density $\left[\mathrm{kg} \cdot \mathrm{m}^{-3}\right], h$ - water depth [m], $S$ - hydraulic slope [-].

The specific bedload transport rate $q_{s}$ in $\left[\mathrm{kg} \cdot \mathrm{s}^{-1} \cdot \mathrm{m}^{-1}\right]$, according to Bagnold's, can be expressed as the following general dependence:

$$
q_{s} \approx\left(\omega-\omega_{0}\right)^{3 / 2} \cdot h^{-2 / 3} \cdot d^{-1 / 2}
$$

where $\omega_{0}$ is a critical value, after exceeding of which the bedload transport is initiated:

$$
\omega_{0}=\tau_{c r} \cdot V
$$

where $\tau_{c r}$ is critical shear stress at the bottom in $\left[\mathrm{kg} \cdot \mathrm{m}^{-2}\right]$.

Based on the analysis of results from study upon transport of bedload material consisting of $d=0.018-300 \mathrm{~mm}$ particle diameter, Bagnold achieved the following dimensionless expression for generalized form of the dependence (3):

$\frac{q_{r}}{q_{r}^{*}}=\left(\frac{\omega-\omega_{0}}{\left(\omega-\omega_{0}\right)^{*}}\right)^{3 / 2} \cdot\left(\frac{h}{h^{*}}\right)^{-2 / 3} \cdot\left(\frac{d}{d^{*}}\right)^{-1 / 2}$

where parameters marked with an asterisk take following constant values: specific bedload transport rate $q_{r}^{*}=0.1$ $\mathrm{kg} \cdot \mathrm{s}^{-1} \cdot \mathrm{m}^{-1}$, specific effective water stream force $\left(\omega-\omega_{0}\right)^{*}=0.5 \mathrm{~kg} \cdot \mathrm{s}^{-1} \cdot \mathrm{m}^{-1}$, water depth $h^{*}=0.1 \mathrm{~m}$, bedload particle diameter $d^{*}=0.0011 \mathrm{~m}$.

To determine the expression value $\left(\omega-\omega_{0}\right)$ in the equation (5), it is necessary to determine the shear stress at the bottom values $\tau_{b}$ and critical bed-shear stress $\tau_{c r}$. The Zagożdżonka riverbed is relatively narrow, and bank slopes and roughness significantly affect the flow resistances in cross-section, as well as the water stream influences on riverbed bottom. Under such circumstances, to determine the shear stress at the bottom $\tau_{b}$, it is necessary to replace the water depth variable $h$ in equation (2) with hydraulic radius $R_{b}$ related to the riverbed bottom. Based on the results of 
hydrometric measurements made within the discharge range from medium to over bankflow, the dependence between hydraulic radius for bottom $R_{b}[\mathrm{~m}]$ and hydraulic radius $R[\mathrm{~m}]$, referring to the whole transverse section of water stream, is defined in the following form:

$$
R_{b}=0.34 \cdot R^{0.55}
$$

To obtain the equation (6), the Einstein's method was used, which assumes that the velocity distribution within cross-section depends on inter-relations between flow resistances arisen at the bottom and river banks. The surfaces area associated with the resistances on riverbed banks and bottom were determined on a base of measured flow velocity distribution within cross-section of the water stream. Then, values of hydraulic radii for these riverbed parts were calculated, which allowed for final establishing the dependence (6). Due to existing flow conditions, the procedure was analogous as in the case of the Bagnold's dependence (5), where, the hydraulic radius for bottom $R_{b}$ was put instead of the water depth $h$.

The critical bed-shear stress values $\tau_{c r}$ for determining the $\omega_{0}$ according to formula (4) were calculated on a base of dimensionless critical Shields parameters $\theta_{c r}$ expressed by the function achieved during laboratory experiments (Popek and Marisch 2004; Popek 2006). Those study involved bottom material collected from the Zagożdżonka riverbed. The bed material with grain's diameters $d_{50}=$ $=0.38$ and $0.41 \mathrm{~mm}$ have had nonuniform size distribution for which values of geometric standard of size distribution curve $\sigma_{g}$ were: $\sigma_{g}=1.53$ and 1.48 , respectively. Formula for $\theta_{c r}$ determina- tion is valid for $R e_{*}>6$ and is of the following form:

$$
\theta_{c r}=0.116-\frac{0.270}{\operatorname{Re}_{*}^{0.5}}+\frac{0.243}{\operatorname{Re}_{*}}+\frac{0.0438}{\operatorname{Re}_{*}^{2}}
$$

where:

$\theta_{c r}=\frac{\tau_{c r}}{\left(\rho_{s}-\rho_{w}\right) g d_{50}}-$ Shields's parameter $R e_{*}=\frac{k_{s}^{\prime} \cdot V_{*}}{v}-$ Reynolds's number related $\rho_{s}-$ specific density of the bed material $\left[\mathrm{kg} \cdot \mathrm{m}^{-3}\right]$;

$\rho_{w}-$ specific density of water $\left[\mathrm{kg} \cdot \mathrm{m}^{-3}\right]$;

$g$ - acceleration of gravity $\left[\mathrm{m} \cdot \mathrm{s}^{-2}\right]$,

$d_{50}$ - characteristic diameter of particles that, along with finer ones, make up $50 \%$ of the bedload sample weight $[\mathrm{m}]$;

$k_{s}^{\prime}$ - grain roughness height of bed material $[\mathrm{m}]$;

$V_{*}=\sqrt{\frac{\tau_{d}}{\rho_{w}}}=\sqrt{g R_{d} J}-\begin{aligned} & \text { dynamic velocity } \\ & \text { within stream to ri- }\end{aligned}$ verbed bottom interaction zone $\left[\mathrm{m} \cdot \mathrm{s}^{-1}\right]$; $v$ - kinematic coefficient of water viscosity $\left[\mathrm{m}^{2} \cdot \mathrm{s}^{-1}\right]$.

\section{RESULTS AND DISCUSSION}

During the flood flow wave, when character of the flow is unsteady, the presence of right-sided histeresis in the dependence between flow discharge vs. bedload transport rate, which indicates that at the same discharges (water stages), the bedload transport rate during the rising of the flood flow wave, is higher than during its falling. Figures 2 and 3 illustrate plots of the dependence between unit values of specific flow discharge in bottom zone $q\left[\mathrm{~m}^{3} \cdot \mathrm{s}^{-1} \cdot \mathrm{m}^{-1}\right]$ and bedload transport rate 
$q_{b}\left[\mathrm{~kg} \cdot 10^{-3} \cdot \mathrm{s}^{-1} \cdot \mathrm{m}^{-1}\right]$ defined for fast-variable flood flow waves No I $\div$ III (Fig. 2) and slow-variable waves No IV $\div$ VII (Fig. 3). Table 1 presents general parameters of water flow and bedload transport measured during analyzed waves. For fast- variable waves (No I $\div$ III), the time $t_{p}$ was $1 \div 2.5 \mathrm{~h}$, i.e. time measured since beginning of the flood event to the peak flow, while for slow - variable waves - it amounted to $7 \div 19 \mathrm{~h}$. It is clear on Figures 2 and 3, that the rising time of flood flow significantly affects the shape of histeresis loop; however, regardless of the wave type, $t_{m b}$, i.e. time measured till the maximum bedload transport rate, was for all cases shorter than $t_{p}$. It means that maximum bedload transport rate occurs sooner than peak discharge (maximum water stage) - it is also apparent from plots on Figures 1 and 2. Data in Table 1 indicate that during the time $t_{f}$, i.e. since maximum flow rate till the end of bedload transport rate measurements, the mean bedload transport rate $q_{b}$ is considerably lower than at time $t_{p}$. In most cases, $q_{b}$ values within analyzed time intervals differ by an order.

The time shift between maximum bedload transport rate and flow discharge results from changed flow resistances which expressed as changes in a hydraulic slope. During the flood flow wave No VII, elevations of water surface were

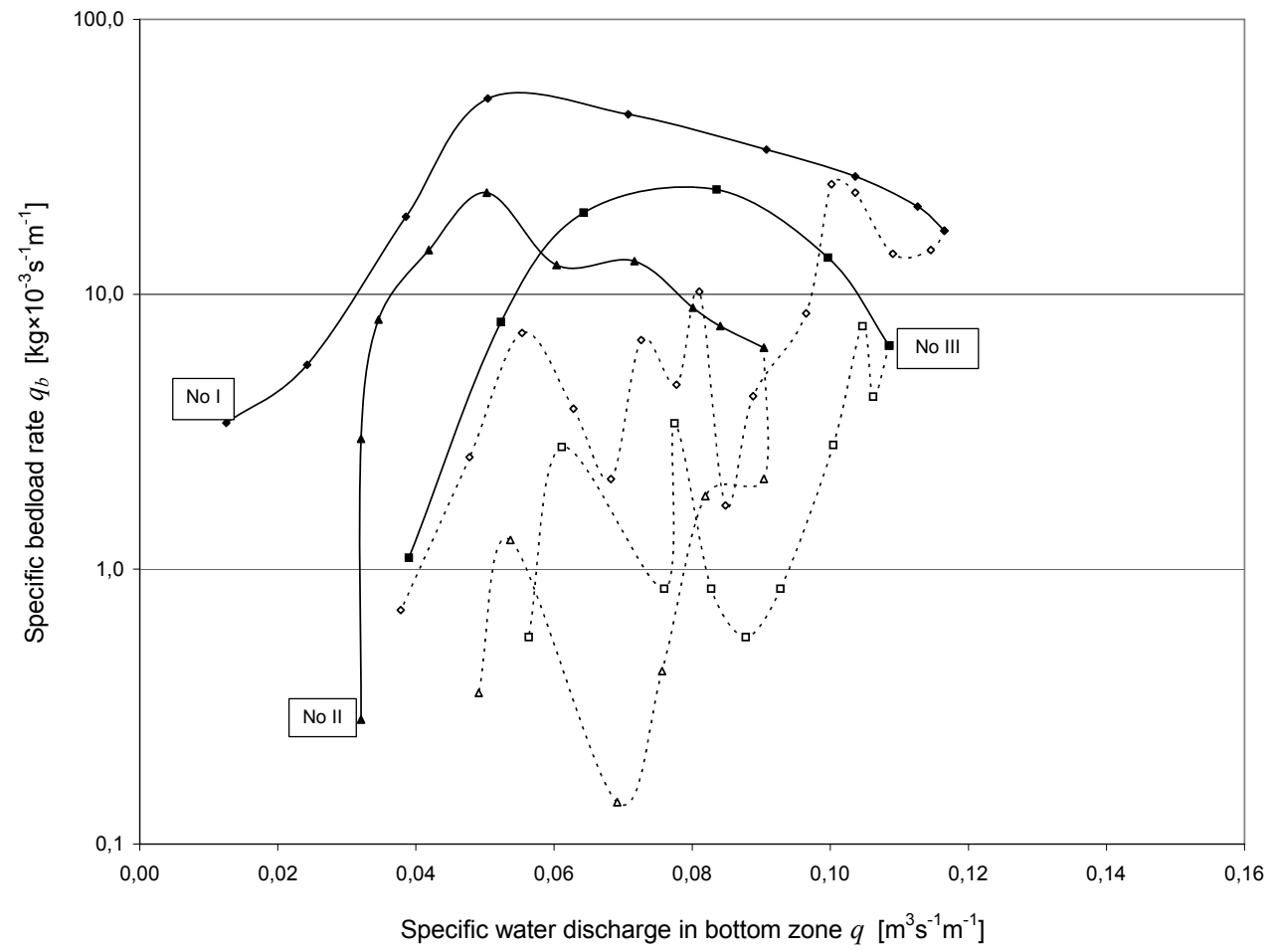

FIGURE 2. Relationship between specific water discharge in bottom zone $q$ and specific bedload rate $q_{b}$ during fast-variable flood flow waves No I, II and III. Notation: solid line and points - raising part of flood wave, dash line and open points - falling part of flood wave 


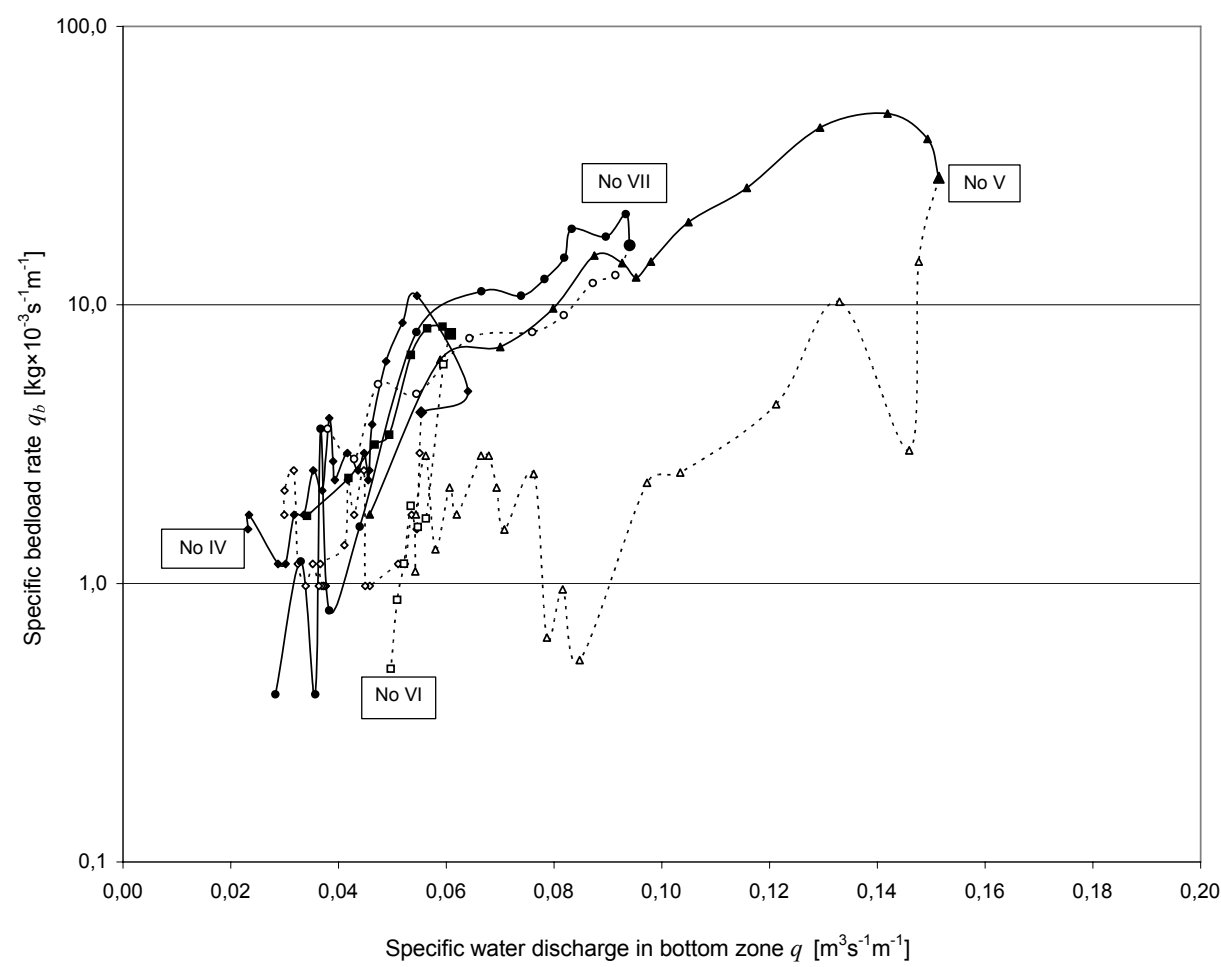

FIGURE 3. Relationship between specific water discharge in bottom zone $q$ and specific bedload rate $q_{b}$ during slow variable flood flow waves No IV, V, VI and VII. Notation: solid line and points - raising part of flood wave, dash line and open points - falling part of flood wave

TABLE 1. Characteristics of analyzed flood flow waves

\begin{tabular}{|c|r|c|c|c|c|c|c|}
\hline \multirow{2}{*}{ Wave No } & \multicolumn{3}{|c|}{ Time* $\mathrm{h}]$} & \multicolumn{2}{c|}{$\begin{array}{c}\text { Mean specific discharge } \\
q\left[\mathrm{~m}^{3} \cdot \mathrm{s}^{-1} \cdot \mathrm{m}^{-1}\right] \text { in time: }\end{array}$} & \multicolumn{2}{c|}{$\begin{array}{c}\text { Mean specific bedload } \\
q_{b}\left[\mathrm{~kg} \cdot 10^{-3} \cdot \mathrm{s}^{-1} \cdot \mathrm{m}^{-1}\right] \text { in time: }\end{array}$} \\
\cline { 2 - 8 } & \multicolumn{1}{|c|}{$t_{p}$} & $t_{m b}$ & $t_{f}$ & $t_{p}$ & $t_{f}$ & $t_{p}$ & $t_{f}$ \\
\hline I & 1.3 & 0.5 & 2.5 & 0.0689 & 0.0801 & 24.8 & 8.65 \\
\hline II & 2.5 & 0.6 & 1.0 & 0.0577 & 0.0700 & 9.82 & 1.03 \\
\hline III & 1.0 & 0.5 & 2.5 & 0.0746 & 0.0846 & 12.2 & 2.46 \\
\hline IV & 17.0 & 15.0 & 53.0 & 0.0410 & 0.0409 & 3.39 & 1.48 \\
\hline V & 14.0 & 12.0 & 30.0 & 0.101 & 0.0845 & 23.3 & 3.52 \\
\hline VI & 7.0 & 6.0 & 51.0 & 0.0743 & 0.0410 & 7.71 & 3.06 \\
\hline VII & 19.0 & 18.0 & 9.0 & 0.0621 & 0.0648 & 10.5 & 3.76 \\
\hline
\end{tabular}

*Notation: $t_{p}$ - time from beginning of flood flow wave to the peak of discharge;

$t_{m b}$ - time from beginning of flood flow wave to the maximum of bedload rate;

$t_{f}$ - time from peak of discharge to the end of the bedload measuring (during falling time of flood flow wave). 
measured above and below the bedload catcher, which made possible to determine the variability in time of water table slopes. The plot illustrating these changes (Fig. 4) indicates that at the beginning of a flood event, after initiating the bedload transport, the water table slope decreased. At subsequent increase of the flood flow wave, the water table slope also raised reaching its maximum value before the peak of wave. When the water stages falling, the water table slopes decreased as well. The slope of water table significantly affects on value of the shear stress at the bottom and thus the bedload transport rate. At the moment of maximum slope of water table, the bedload transport rate reached its maximum value as well. In turn, diverse values of the water table slopes during the rising and falling times of flood flow wave, makes the hysteresis between flow discharge and bedload transport rate appears.

Particular variability in water table slopes during the flood event and bedload transport measurements allowed for performing the comparative calculations using the Bagnold's equation (5) as well as formulas (6) and (7) defined by the Author. The plot (Fig. 5) illustrates the hydrograph of a water stages during the flood flow wave No VII, as well as

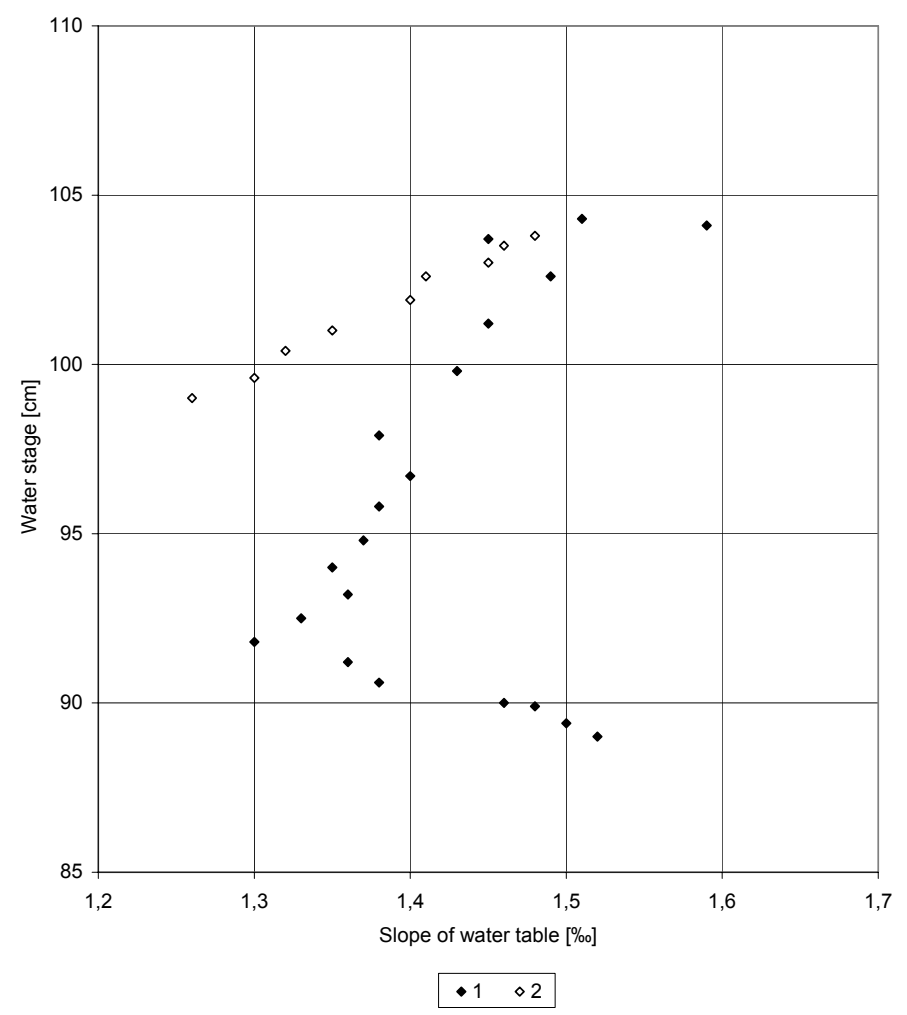

FIGURE 4. Water table slop changes during flood flow wave No VII. Notation: solid points - raising of flood wave, open points - falling of flood wave 


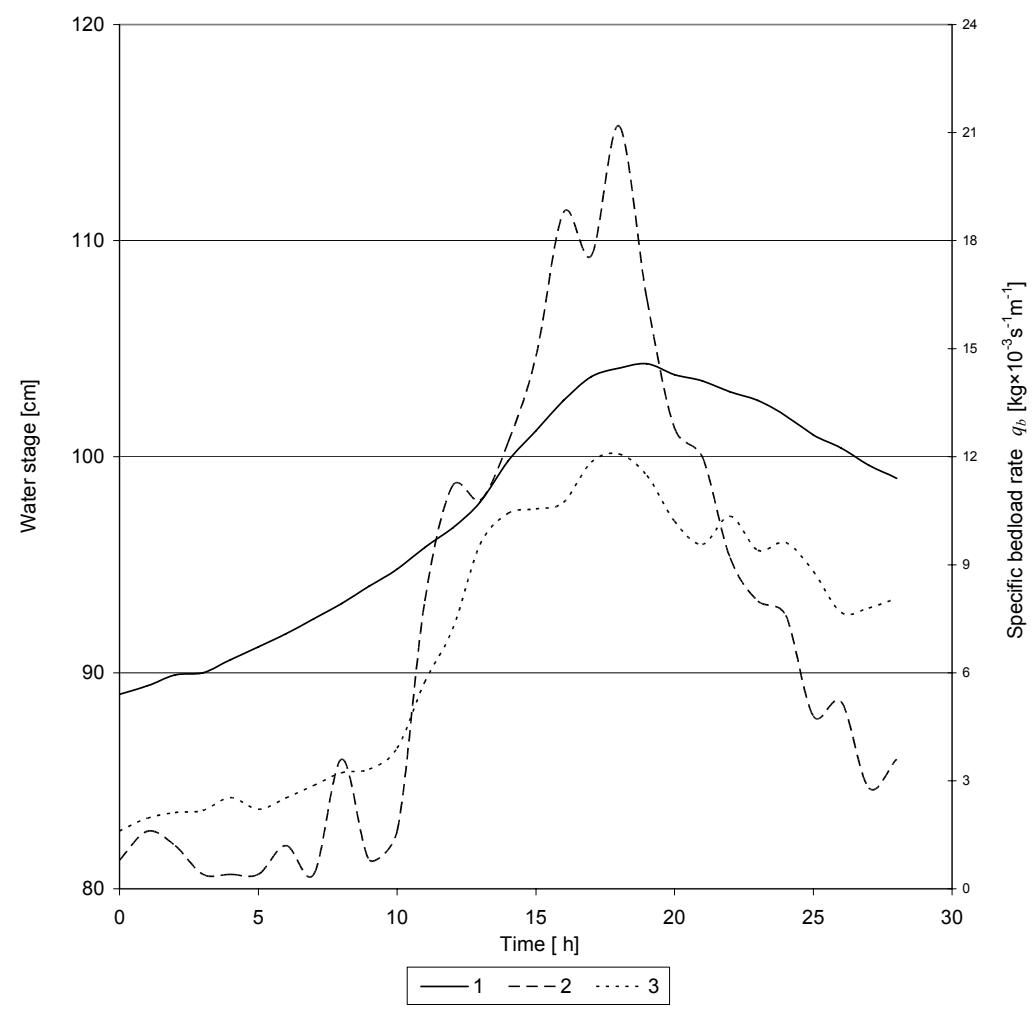

FIGURE 5. Hydrograph of water stages (1) during flood flow wave No VII and variability of measured specific bedload rate (2) and calculated one by using Bagnold's formula (3)

the variability of bedload transport rate determined on a base of in situ measurements, which was compared with data achieved from calculations. It is apparent that plots made on a base of measurements and calculations differ in respect to bedload transport rate values. Instead, the maximum value appears at the same time in both cases. The total mass of the bedload was compared as well. In that case, quite good result conformity was achieved: according to measurements, it amounted to $746 \mathrm{~kg}$, while calculations revealed $701 \mathrm{~kg}$, which was only by about $6 \%$ lower.

\section{CONCLUSIONS}

Performed survey and comparative calculations made possible to draw the following conclusions:

1. The bedload transport rate is characterized by great variability that is particularly apparent during the rising time of the flood flow wave. The histeresis phenomenon occurs then, which is observed as the dependence between flow discharge (water stage) vs. bedload transport rate.

2. The histeresis phenomenon is influenced by a variability of flow resistances expressed as differentiation in the 
slopes of water table during rising and falling of the water stages.

3. Maximum bedload transport rate during flood flow wave occurs earlier than peak of flow discharge (maximum water stage).

4. In calculations made according to the Bagnold's formula, the specific water stream force was determined by means of Author's empirical formula. Quite great conformity between measured and calculated mass of a bedload transported during one of the analyzed flood event, was obtained. Therefore, it can be a basis for the assumption that presented calculating procedure may be applied under unsteady flow conditions if data on flow parameters variability, including temporary slopes of water table, are accessible.

\section{REFERENCES}

BAGNOLD R.A. 1986: Transport of solids by natural water flow: evidence for world-wide correlation. Proceedings of the Royal Society of London, A 405, 369-374.

BARTNIK W., MICHALIK A. 2000: Development of research on bedload transport and their practical verification (in Polish). Proceedings of Polish Nationwide School of Hydraulic, Kraków-Ustroń-Jaszowiec, Water Management Committee Polish Academy of Science, Gdańsk, 19-38.

DVWK 1992: Geschiebemessungen. Deutscher Verband für Wasserwirtschaft und Kulturbau, Regeln zur Wasserwirtschaft, Heft 127, 53.

HOEY T.B. 1992: Temporal variations in bedload transport rates and sediment storage in gravelbed rivers. Progress in Physical Geography, 16, p. 319-338.

KUHNLE R. 1991: Bed load transport on two small streams. Proceedings of the Fifth Federal Interagency Sedimentation Conference, Las Vegas, Nevada, 4-139, 4-146.

MICHALIK A. 2000: Bedload transport in mountain rivers - measurements and results. Pro- ceedings of 10th Int. Conf. on Transport and Sedimentation of Solid Particles. Zeszyty Naukowe Akademii Rolniczej we Wrocławiu, 382, 41-58.

POPEK Z. 2006: Bedload transport condition in small lowland river (in Polish). Treatises and Monographs, 300, SGGW Publishing, Warsaw.

POPEK Z., MARISCH K. 2004: Shear stress in open channel with flat sandy bottom (in Polish). Acta Scientiarum Polonorum - Architectura 3 (1), 37-53.

REID I., FROSTICK L.E., LAYMAN J.T. 1985: The incidence and nature of bedload transport during flood flows in coarse-grained alluvial channels. Earth Surface Processes and Landforms, 10, 33-44.

SHEN Z. 1998: Veränderung des Geschiebetransports durch naturnahe Soleneinbauten. Institut für Wasserwesen, Universität der Bundeswehr München, Mitteilungen, Heft 63.

SKIBIŃSKI J. 1976: A trial on quantitative estimation of bedload discharge in the rivers of the Central Poland (in Polish). Treatises, 74, SGGW Publishing, Warsaw.

Streszczenie: Zmienność natężenia ruchu rumowiska wleczonego w czasie wezbrań w rzece Zagożdżonce. $\mathrm{W}$ pracy przedstawiono wyniki pomiarów transportu rumowiska wleczonego w czasie siedmiu wezbrań obserwowanych w rzece Zagożdżonce. Do pomiaru wleczenia wykorzystano łapacz rumowiska wyposażony $\mathrm{w}$ aparaturę do ciągłego pomiaru i automatycznej rejestracji masy zatrzymanego w nim rumowiska. Na podstawie parametrów hydraulicznych zarejestrowanych podczas przepływu jednej z analizowanych fal wezbraniowych obliczono wartości chwilowe jednostkowego natężenia ruchu rumowiska wleczonego. W obliczeniach wykorzystano formułę Bagnolda, przy czym naprężenia graniczne określono według formuły autora, ustalonej na podstawie badań laboratoryjnych. Zmierzone chwilowe wartości natężenia wleczenia oraz całkowitą masę rumowiska wleczonego porównano $\mathrm{z}$ wartościami obliczonymi.

\section{MS. received April 2010}

Author's address:

Katedra Inżynierii Wodnej i Rekultywacji

Środowiska SGGW

02-776 Warszawa, ul. Nowoursynowska 159

Poland 